\title{
Quality evaluation of differently processed whole egg powder yield, nutritional value
} and microbial load

${ }^{1}$ Daramola-Oluwatuyi, E.I., ${ }^{1}$ Olugbemi, T.S. and ${ }^{2}$ Jiya, E. Z.

${ }^{1}$ Department of Animal Science, Ahmadu Bello University, Zaria, Kaduna State, Nigeria.

${ }^{2}$ Department of Animal Production, Federal University of Technology,

Minna, Niger State, Nigeria.

Corresponding author: daramolaifeouwa@gmail.com;

Abstract $+2347039399328$

Egg is a nutrient dense food, however the cylical egg glut characterized by egg spoilage, quality deterioration and wastage imparts negatively on poultry farmers. Powdered dried egg provides a convenient alternative to this problem. The focus of this study was to compare and evaluate differently processed whole eggs into powder egg. An experiment was conducted to evaluate the potential of whole egg powders made from different processing methods. The yield, proximate composition, microbiological load from differently processed (Spray dried-commercial, Freeze dried and Dehydrated) whole egg powders were compared. The treatments in this experiment were the Spray Dried, Freeze Dried and Dehydrator Dried Whole Egg Powders represented as SDWEP, FDWEP and DDWEP, respectively. Thirty-five eggs each were used to produce the FDWEP and DDWEP while the SDWEP was obtained from United State of America. The Experimental design was a completely randomized design. Powder percentage yield of $1000 \mathrm{~g}$ raw eggs (26.7\%) and crude protein $(52.78 \%)$ was highest $(P<0.05)$ from SDWEP. Salmonella spp observed in raw eggs was destroyed by heat from the processing methods in the whole egg powders. The microbial load was within the $2 \mathrm{cfu} / \mathrm{g}$ acceptable limits. This study concludes that whole egg powders produced by spray, freeze or dehydrator methods are generally accepted and serve as good alternatives to fresh eggs in addition to their use in the confectionary industry not compromising the final product quality.

Keywords: whole egg powder, microbes, product quality

Évaluation de la qualité des œufs entiers transformés en poudre, de la valeur nutritionnelle et de la charge microbienne

\section{Résumé}

$\overline{\text { L'œuf est un aliment riche en nutriments, mais la surabondance d'œufs cyclique caractérisée }}$ par la détérioration des oufs, la détérioration de la qualité et le gaspillage affecte négativement les éleveurs de volaille. L'œuf séché en poudre offre une alternative pratique à ce problème. L'objectif de cette étude était de comparer et d'évaluer des oufs entiers transformés différemment en oufs en poudre. Une expérience a été menée pour évaluer le potentiel des poudres d'œufs entiers fabriquées à partir de différentes méthodes de traitement. Le rendement, la composition approximative, la charge microbiologique de poudres d'oufs entiers traitées différemment (séchées par pulvérisation-commerciales, lyophilisées et déshydratées) ont été comparées. Les traitements dans cette expérience étaient les poudres d'œufs entiers séchés par pulvérisation, lyophilisés et séchés au dés hydrateur représentés respectivement par SDWEP, FDWEP et DDWEP. Trente-cinq oufs chacun ont été utilisés pour produire le FDWEP et le DDWEP tandis que le SDWEP a été obtenu des États-Unis d'Amérique. Le plan expérimental était un plan complètement 
randomisé. Le pourcentage de rendement en poudre de $1000 \mathrm{~g}$ d'œufs crus $(26,7 \%)$ et de protéines brutes $(52,78 \%)$ était le plus élevé $(P<0,05)$ du SDWEP. Salmonella spp observée dans les aufs crus a été détruite par la chaleur des méthodes de traitement dans les poudres d'œufs entiers. La charge microbienne était dans les limites acceptables de $2 \mathrm{cfu} / \mathrm{g}$. Cette étude conclut que les poudres d'œufs entiers produites par pulvérisation, congélation ou déshydratation sont généralement acceptées et constituent de bonnes alternatives aux oufs frais en plus de leur utilisation dans l'industrie de la confiserie sans compromettre la qualité du produit final.

Mots-clés : poudre d'œuf entier, microbes, qualité du produit

\section{Introduction}

United State Department of Agriculture (2013) as cited by Heise et al. (2015) reported that of the various components of animal husbandry, poultry farming is the most popular and probably lucrative. Nigerian Federal and State governments are investing in poultry production.Egg production plays a vital role in poultry farming and has been on the increase with various government programmes such as "Feed the School Children"encouraging more people to embark on poultry production as quoted by Heise et al. (2015). Eggs are laid by female animals of many different species, including birds, reptiles, amphibians, mammals, and fish, however among other avian the most popular choice for egg consumption are chicken eggs. They are a cost effective animal protein with a potential to contribute to food and nutrition security and generate rural household livelihoods (Lannotti et al., 2014). Eggs are low in saturated fats and are good sources of high quality protein and varying amounts of 13 essential vitamins and minerals, including Vitamin A, B12 and folate hence them being termed as a "nutritional powerhouse". (Lauber, 2007; 2017). Eggs are extremely perishable and must be kept refrigerated as they have a relatively short shelf life. They are also delicate and bulky thereby having increased risk of breakage during transportation. (Lauber, 2007; 2017). The cyclical egg glut in Nigeria characterized by egg spoilage, egg quality deterioration, and wastage in the process of transporting excess eggs which eventually results in loss of inputs to poultry farmers which spans for about 3 months /year is on the increase as more individuals embark on poultry production in order to alleviate poverty and unemployment.Powdered dried eggs provide a convenient alternative to fresh eggs and add quality and consistent performance to the list of attributes. In addition, dry egg products can be stored up to a year or longer under proper storage conditions. The risk of bacterial contamination due to improper handling is significantly reduced as well as the cleanup time. Powdered dried eggs are a solution to bulkiness and fragility of fresh eggs as well as storage challenges as they can be stored up to a year or longer under proper storage conditions (Jay, 2000). Egg glut over a period of time results in a compromise of egg quality (deterioration and spoilage). The attempt to transport excess eggs from one location to another in times of glut has its attendant problem of egg breakage and deterioration of the internal quality thereby enhancing micro-organism penetration. Powdered eggs are popular in several developed countries with little or no differences reported between fresh eggs and egg powder. However, in Nigeria, despite the achievements in agriculture most especially in poultry-egg production, there exist still limited or practically no provision for handling processing of eggs. This study evaluated some adaptable processes of transforming fresh eggs into whole egg powder thereby extending its shelf-life 


\section{Daramola-Oluwatuyi, Olugbemi and Jiya}

while still maintaining its richness in comparison to an imported powder with focus on the yield, nutrient composition and microbial load.

\section{Materials and methods Study area}

The experimental sites were the Animal Products and Biochemical Laboratories, Department of Animal Science, Faculty of Agriculture, Ahmadu Bello University, Samaru, Zaria, and Vetco diagnostic laboratory, Kaduna, Nigeria.

\section{Experimental procedures}

Production and evaluation of differently processed whole egg powders

\section{Egg powder production}

Two processing methods (Freeze dried and Dehydrator) were employed in making the whole egg powder from fresh eggs at the Bayero University Central Laboratory, Kano and Biochemistry Laboratory, Ahmadu Bello University, Zaria respectively.

The Freeze Drying method entailed using thirty-five (35) pieces of commercial layer egg obtained from National Agricultural Extension and Research Liaison Services (NAERLS) farm. They were neatly unshelled and whisked thoroughly with the aid of a Sonik Japan Model, SB-1515 blender to ensure albumen-yolk homogenization, then the mixture was placed in a SB4L Freeze dryer set at $-40^{\circ} \mathrm{c}$ and left to dry for 48 hours. After 18 hours of drying, the eggs were stirred randomly to ensure uniform drying and to prevent molding together. After drying, the eggs which appeared in a dried-crumbled form were blended with a dry blender set at 'max' for 30 seconds to get the egg powder product. The whole egg powder was packed and stored in Ziploc bags of 3 X 6" dimension for further evaluation.

Another 35 egg pieces obtained from NAERLS farm were used for the Dehydrator method. The eggs were unshelled and whipped up with the aid of a blender to enhance homogeneity, thereafter the egg slurry was poured into a fruit-roll sheet (a tiny non-stick layer attached to the dehydrator) and then the temperature of the dehydrator (PRESTO Dehydro digital electric food dehydrator 06301) was set at $145 \mathrm{oF}(62.8 \mathrm{oC})$. The whole egg slurry was allowed to dry for 19 hours until they were completely in brittle form. The dried brittle egg was packed and poured into a dry blender set at 'max' for 30 seconds and blended into powder. The whole egg powder was stored as above and subjected to proximate and microbial analyses while comparing them to the whole egg powder processed using Spraying drying method (as indicated by the manufacturer) imported from United State of America (USA).

\section{Proximate composition analysis}

The Commercial, Freeze and Dehydrator dried whole egg powder samples were analysed for proximate composition according to AOAC (2005) procedure.

\section{Dry matter (DM)}

Moisture content determination was carried out using the air oven method. Crucibles were washed and dried in an oven. They were allowed to cool in the desiccator and the weight was noted. The samples were dried at temperature $60^{\circ} \mathrm{C}$ for 3 days. The dried samples were cooled in a desiccator and weighed. They were later returned to oven and the process continued until constant weights were obtained.

DM $=$ Weight of sample before drying $(\mathrm{g})$ Weight of sample after drying (g) X 100

before drying

Weight of sample

\section{Crude protein}

The crude protein content was determined using micro Kjeldahl method as described (AOAC, 2005).

\section{Ash value}

$1 \mathrm{~g}$ of dried samples was weighed into clean, dried preciously weighed crucibles. The samples were ignited over a low flame to char the organic matter using and electro 
thermal heat. The crucibles were then placed in muffle furnace at $600 \mathrm{oC}$ for hours until it ashed completely. The ashed samples were then transferred directly to desiccator, cooled and weighed immediately.

$\%$ ash $=$ Initial weight $(\mathrm{g})-$ ash weight $(\mathrm{g})$ $\underline{100}$

\section{(g)}

Initial weight

\section{Ether extract (crude fat)}

The soxhlets extraction method was used according tomethods described by Association of Official Analytical Chemists (AOAC, 2005).

\section{Microbial analyses}

Preparation of media: Plate Count Agar and McConkey agar media were utilized for total bacteria count and coliform count. Sabauroud dextrose agar media was used for isolation of fungi after incubation for 2-3 days at room temperature and triple sugar irons agar for selective isolation and identification of Salmonella spp. All the media were prepared following the manufacturer's instruction and sterilized by autoclaving at $121^{\circ} \mathrm{C}$ for 20 minutes following the method described by OseiSomuah et al. (2003).

Total bacteria, coliform and noncoliform: Total bacteria, coliform and noncoliform counts were determined by the spread plate method as reported by Bartram et al. (1996). Plates showing colonies were selected, counted and the results were presented in $\mathrm{CFU} / \mathrm{g}$.

Fungi culture: Fungi were identified by colonial and cellular morphology using lacto-phenol cotton blue staining technique. Tests were carried out according to Holt (1994) methods.

Selective isolation of Salmonella spp: A sterile inoculating wire loop was used to pick a colony from the non-coliform growth on the McConkey medium and sub-cultured on the triple sugar Iron agar in a slant tube. The inoculated medium was then incubated for 24 hours at $37^{\circ} \mathrm{C}$. This procedure was repeated for all the samples.

\section{Data analysis}

Data obtained were analyzed using One Way ANOVA statistical model. Means and mean differences were compared using Duncan's multiple range tests, SAS 9.0 (SAS 1993).

\section{Results \\ Product yield}

The yield of egg powder per egg obtained from the freeze, dehydrator and spraying drying processing methods amounted to $4.33 \mathrm{ml} / \mathrm{g}, 4.47 \mathrm{ml} / \mathrm{g}$ and $4.62 \mathrm{ml} / \mathrm{g}$ respectively which translated to $23.1 \%$, $22.4 \%$ and $26.7 \%$ for the various processes respectively. Approximately, 1 egg gave $12 \mathrm{~g}, 12.7 \mathrm{~g}$ and $16.3 \mathrm{~g}$ (the manufacturer stated clearly that 92 'Big' eggs were used to make $1500 \mathrm{~g}$ of egg powder on the container) of whole egg powder for FDWEP, DDWEP and SDWEP respectively.

\section{Proximate composition of egg powders}

The proximate composition of differently processed and commercial whole egg powders are outlined in Table 2. There were significant differences $(\mathrm{P}<0.05)$ across the treatments for dry matter, crude protein and nitrogen free extract for all the processed whole egg powders. For dry matter, FDWEP has the significantly lowest value of 92.28 while DDWEP recorded 93.93 and having the highest value of 95.00. Crude protein for SDWEP also has the highest significant value 52.78 while FDWEP and DDWEP had similar significantly lower values of 49.92 and 50.71 respectively. However, for Nitrogen free extract, the reverse was the case as SDWEP value (42.37) was significantly the lowest recorded while FDWEP and DDWEP values were higher (44.36 and 44.38) respectively. There were no significant differences $(\mathrm{P}<0.05)$ for values derived from Ether extract and Ash. 


\section{Daramola-Oluwatuyi, Olugbemi and Jiya}

Microbial load of egg powders

Table 3 shows the microbiological load of differently processed whole-egg powders. There were no significant differences $(\mathrm{P}>0.05)$ across the treatments for total coliform count, non-coliform count, total bacterial count and yeast count. Significant $(\mathrm{P}<0.05)$ differences however occurred for mold count across treatments with FDWEP having the highest (0.330CFU) and differing from the other treatments. Salmonella was negative across the powder treatments and positive for raw egg while E.coli was negative across all the treatments. Salmonella was negative across the powder treatments and positive for raw egg while E.coli was negative across all the treatments.

\section{Discussion}

\section{Product yield}

Fro the results shown in Table 1, the yield of each power was generally affected by the processing methods used (freeze drier, dehydrator and spray drying (method adopted for th commercial egg powder). These methods are characterized by the reduction in the initial quantities of the liquid and higher quality concentration in the product. The spray drier method of drying whole egg liquid showed higher significance over the dehydrator and freeze drier in terms of powder quantity which could have resulted from the initial egg sizes used for the sprayed dried product. Despite this variation, the egg powder yield obtained from all the drying methods compared favorably with the yield percentage result of $(21.90 \%)$ oven dried chicken eggs reported by Abdullahi (2016). Proximate composition of egg powders Dry matter of any substance reveals to what extent the moisture level of that substance was drained/dried based on the varying temperature degree viz a viz time duration (usually in hours) it was exposed to and this could determine to an extent the level at which the products will succum to microbial damage over time. The significantly higher dry matter value $(95.00 \%)$ recorded for the Spray Dried Whole Egg Powder (SDWEP) is a reflection of the higher efficiency in dryness of the spray dryer in drying process of the liquid egg as against the other method. Although the values obtained from other processing falls within the acceptable values of powdered substance dry matter levels. The higher crude protein value also recorded for the SDWEP is probably a consequence of the higher retention of nutritional properties especially the protein found in spray drying of food materials. Ether extract and Ash contents across the treatments had no significant differences with Freeze Dried Whole Egg Powder (FDWEP) having (3.77, 1.96), DDWEP (3.37, 1.92) and SDWEP (3.02, 1.84) respectively. Crude protein and Nitrogen free extract results of the two processed powders (FDWEP, DDWEP) had similar results while a lower value of 42.37 was obtained for SDWEP. All the results values above were similar to ranges obtained by Mine (2007) and Woo and Bhandri(2013).

\section{Microbial load of egg powders}

This result agrees with Gibbons et al. (2011) who stated that over $99 \%$ of the Salmonella organisms in liquid egg were killed on drying in an experimental spray dryer. The significant mould count recorded in the FDWEP group could be as a result of its slightly higher moisture content. 
Quality evaluation of differently processed whole egg powder yield, nutritional value and microbial load

Table 1: Yield of differently processed egg powder

\begin{tabular}{llll}
\hline Yield & $\mathbf{g} / \mathbf{m l}$ & $\mathbf{G}$ & $\mathbf{\%}$ \\
\hline FDWEP & 4.33 & 12 & 23.1 \\
DDWEP & 4.47 & 12.7 & 22.4 \\
SDWEP & 4.62 & 12.3 & 26.7 \\
\hline
\end{tabular}

FDWEP- Freeze dried whole egg powder

DDWEP- Dehydrator dried whole egg powder

SDWEP- Spray dried whole egg powder

$\mathrm{g} / \mathrm{ml}$ - gramper millimeter, g- grams, \%- percentage

Table 2: Proximate composition of differently processed whole-egg powders

\begin{tabular}{lllll}
\hline Nutrients & FDWEP & DDWEP & SDWEP & SEM \\
\hline Dry matter & $92.28^{\mathrm{c}}$ & $93.93^{\mathrm{b}}$ & $95.00^{\mathrm{a}}$ & 0.25 \\
Crude protein & $49.92^{\mathrm{b}}$ & $50.71^{\mathrm{b}}$ & $52.78^{\mathrm{a}}$ & 0.50 \\
Ether extract & 3.77 & 3.37 & 3.02 & 0.39 \\
Ash & 1.96 & 1.92 & 1.84 & 0.08 \\
Nitrogen free extract & $44.36^{\mathrm{a}}$ & $44.38^{\mathrm{a}}$ & $42.37^{\mathrm{b}}$ & 0.42
\end{tabular}

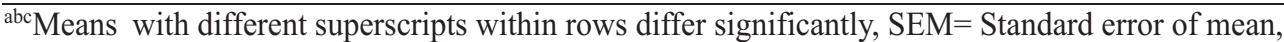
FDWEP $=$ Freeze dried whole egg powder, DDWEP= Dehydrator dried whole egg powder, SDWEP = Spray dried whole egg powder.

Table 3: Microbial load of differently processed whole-egg powders

\begin{tabular}{lllll}
\hline Parameters & FDWEP & DDWEP & SDWEP & SEM \\
\hline Total-coliform count $(\mathrm{CFU} / \mathrm{ml} / \mathrm{g})$ & 0.000 & 0.000 & 0.000 & 0.000 \\
Non-coliform count $(\mathrm{CFU} / \mathrm{ml} / \mathrm{g})$ & 0.042 & 0.019 & 0.030 & 0.540 \\
Total bacteria count $(\mathrm{CFU} / \mathrm{ml} / \mathrm{g})$ & 0.175 & 0.120 & 0.136 & 0.570 \\
& & & & \\
Mold count & $0.330^{\mathrm{b}}$ & $0.000^{\mathrm{a}}$ & $0.000^{\mathrm{a}}$ & 0.002 \\
Yeast count & $-\mathrm{ve}$ & $-\mathrm{ve}$ & $-\mathrm{ve}$ & \\
Salmonella spp & $-\mathrm{ve}$ & $-\mathrm{ve}$ & $-\mathrm{ve}$ & \\
E. coli & $-\mathrm{ve}$ & $-\mathrm{ve}$ & $-\mathrm{ve}$ &
\end{tabular}

${ }^{\mathrm{ab}}$ Means with different superscripts within rows differ significantly $(\mathrm{P}<0.05), \mathrm{SEM}=$ Standard error of mean, FDWEP $=$ Freeze dried whole egg powder, DDWEP $=$ Dehydrated dried whole egg powder, SDWEP $=$ Spray dried whole egg powder.

\section{Conclusions}

Production of egg powder with the aid of a dehydrator and freeze drier was established and dehydrator use for egg powder production is effective and can be adopted by home users as much as producers.

The yield percent of $1000 \mathrm{~g}$ raw egg from freeze dried, dehydrator and commercial egg powder were $23.1 \%, 22.4 \%$ and $26.7 \%$ respectively.

Freeze dried and dehydrated whole egg powders compare favourably with the commercial (imported-standard which is spray dried) whole egg powder in all spheres of evaluation.
Further studies can be carried out in evaluating the nutritional value of products made from egg powder.

\section{References}

Abdullahi, A. A. 2016. Quality characteristics and processing yield of egg powder from different poultry species. MSc. Thesis submitted to the Department of Animal Science, University of Ibadan. 1-62.

AOAC, 2000. Association of Official Analytic Chemist.Official Method of Analysis. (17 $7^{\text {th }}$ Edition), 
Gaithersburg, MD.

Bartram, J., Balance, R. and Pedley, S. 1996. Microbiological Analyses: Water Quality Monitoring - A Practical Guide to the Design and Implementation of Freshwater Quality Studies and Monitoring Programmes. Published on behalf of United Nations Environment Programme and the World Health Organization. (C) 1996 UNEP/WHOISBN 0419223207 (Hbk) 0419217304 (Pbk), 10:7.

Heise, H., Crisan, A. and Theuvsen, L. 2015. The Poultry Market in Nigeria: Market Structures and Potential for Investment in the Market. International Food and Agribusiness Management Review.18(1): 199.

Holt, J. G. 1994. Bergeys Manual of Determinative Bacteriology. 9thEdition., Williams and Wilkins Baltimore. 787

Jay, M. J. 2000. Modern Food Microbiology.6th Edition. Aspen

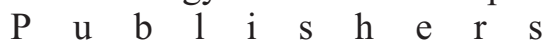
Incoporated., Gaithersburg, Maryland.

Lannotti, L. L., Lutter, C.K., Bunn, D.A. and Stewart, C.P. 2014. Eggs: The uncrackedpotential for improving maternal and young child nutrition among the world's poor. Nutrition Reviews, 72(6): 355-368.

Lauber, M. 2007. Transport and Care of Poultry: Fact sheet- for poultry at saleyardsDepartment of Primary Industries: Victorian Government Department of Primary Industries. Updated: 8th of July, 2017; Retrieved: 9th of June 2018. http://agriculture.vic.gov.au/agricu lture/livestock/poultry-andeggs/transport-and-care-ofpoultry
Mine, Y. 2007. Structure and chemical composition of eggs.Egg Bioscience and Biotechnology. 15. https://doi.org/10.1002/978047018 $1249 /$

Osei-Somuah, A., Otsyina, H.R., Arthur, C.T., Nortey, P.W.K. and Hammond, V. 2003. Microbial Quality of table eggs sold on selected markets in Accra. Ghana Veterinary Medical Association BiAnnual Newsletter. 6(2):314-318.

SAS 1993. Statistical Analysis System, coda computer software, version 9; statistics, SAS Institute Incorporated, Cary, NC27513, USA.

Woo, M. W. and Bhandri, B. 2013. Spray drying for food powder production. Handbook of Food Powders: Processes and Properties. 29-56.

Received: $13^{\text {th }}$ June, 2021 Accepted: $28^{\text {th }}$ September, 2021 